\title{
Optimization of Admixture and Three-Layer Particleboard Made from Oil Palm Empty Fruit Bunch and Rubberwood Clones
}

\author{
Syeed Osman Al-Edrus Saiful Azry, Paridah Md Tahir \\ and Juliana Abdul Halip
}

\begin{abstract}
Empty fruit bunch (EFB) is a biomass that is widely available and has the potential to be used as industrial raw material especially in wood-based industries. This study focuses on producing a particleboard by incorporating EFB with two different rubberwood clones: Prang Besar (PB) 260 and RRIM 2002, respectively. PB 260 is a commercially planted clone and wood from matured ( $>25$ year-old) trees are used by wood-based panel manufacturers. RRIM 2002 is a new clone planted at the Malaysian Rubber Board (MRB) research trial plots and consists of only 4-yearold trees. Two types of particleboards (admixture and three-layer) with different ratios were produced. The Japanese Industrial Standard (JIS-5908 2003 particleboard) was used to evaluate mechanical and dimensional stability properties of the particleboards. From the study, it was found that admixture particleboards showed superior properties compared to three-layer particleboards. Layering EFB and rubberwood significantly decreased board performance for all properties (except internal bonding). The optimum ratios of EFB and both rubberwood clones are found to be 1:1 (50\% EFB: $50 \%$ rubberwood). Meanwhile, increasing the rubberwood clones ratio to $70 \%$ lowered board performance especially for EFB (30\%):RRIM 2002 clone $(70 \%$ ) boards which showed the lowest values for all properties for both admixture and three-layer boards.
\end{abstract}

Keywords Empty fruit bunch - Admixture - Layer - Rubberwood P Particleboard · Mechanical properties $\cdot$ Physical properties

\footnotetext{
S. O. Al-Edrus Saiful Azry $(\bowtie) \cdot$ Paridah Md Tahir · Juliana Abdul Halip Institute of Tropical Forestry and Forest Products (INTROP), Universiti Putra Malaysia, 43400 UPM Serdang, Selangor, Malaysia e-mail: julianahalip@gmail.com

Paridah Md Tahir

Faculty of Forestry, Universiti Putra Malaysia, 43400 UPM Serdang, Selangor, Malaysia
} 


\section{Introduction}

The oil palm (Elaeis guineensis Jacq.) is an allogamous arborescent monocot of the Arecaceae family (Hartley, 1988). In Malaysia, oil palms are normally present as single-stemmed, can reach a height of up to $20 \mathrm{~m}$, and can be cultivated easily. Malaysia is the second largest exporter and producer of palm oil in the world, with a total oil palm planted area of 5.230 million hectares as of December 2013 (Table 1; MPOB 2014). The main product from oil palm is palm oil while the rest of the biomass waste is either burned (as the main energy source for power generation in palm oil mills) or dumped as organic fertilizer through natural decomposition (Yusoff 2006; Ng et al. 2012). Biomass of oil palm, namely empty fruit bunch (EFB), mesocarp fibre, palm kernel shell, and palm oil mill effluent are produced daily and are more consistent in terms of supply compared to oil palm trunks (Roslan et al. 2011). Nowadays, palm biomass have gained more attention and are being used as raw material for the production of plywood, laminated lumber, pellets, high-value chemicals, and other products (Sulaiman et al. 2011; Ng et al. 2012).

As reported by KeTTHA (2011), most of the EFB in Malaysia is used in soil mulching as an organic nutrient to reduce the input of inorganic fertilizer. Rahim (2010) mentioned that there are mills that produce particleboards from EFB in Malaysia. However, most particleboard mills in Malaysia use mainly rubberwood as the raw material as rubberwood is regarded as the conventional raw material for the production of particleboard and medium-density fibreboard (MDF) in Malaysia. Presently, Malaysia has 16 particleboard mills which use rubberwood as their major raw material (NATIP (2009). Nevertheless, with an ever-increasing demand for rubberwood, especially from the furniture industry, the rubberwood supply is being strained. Based on Ratnasigam et al. (2011), the total export value of rubberwood products grew by $39.44 \%$ in 2009 compared to 2000 . However, issues regarding the shortage of rubberwood supply are a growing concern due to declining rubber plantation areas (Ratnasigam et al. 2011). To date, various efforts have been made to incorporate the usage of rubberwood with other lignocellulose materials including EFB biomass. Oil palm EFB has been seen as an abundant, readily available, and cheap resource for board manufacturing. In terms of fibre strength properties, it has been proven to be comparable with the properties of rubberwood. In addition, high toughness and cellulose content values of EFB make it suitable for composite

Table 1 Malaysia oil palm planted area. (Source: MPOB 2014)

\begin{tabular}{l|l}
\hline Year & Planted area (million hectares) \\
\hline 2007 & 4.304 \\
\hline 2008 & 4.487 \\
\hline 2009 & 4.691 \\
\hline 2010 & 4.853 \\
\hline 2011 & 5.000 \\
\hline 2012 & 5.077 \\
\hline 2013 & 5.230 \\
\hline
\end{tabular}


Table 2 Empty fruit bunch and rubberwood fibre properties

\begin{tabular}{l|l|l}
\hline Fibre properties $(\mu \mathrm{m})$ & Empty fruit bunch & \\
\hline Length & 990 & Rubberwood $^{\mathrm{b}}$ \\
\hline Diameter & 19.1 & 1249 \\
\hline Lumen & - & 29.63 \\
\hline Cell wall thickness & 3.38 & 20.28 \\
\hline
\end{tabular}

${ }^{a}$ Law et al. 2007

${ }^{\text {b }}$ Naji et al. 2011

applications (Sreekala et al. 2004; John et al. 2008). Fresh EFB from the mill was reported to contain $30.5 \%$ lignocelluloses ( $45.0 \%$ cellulose, $32.8 \%$ hemicelluloses, and $20.5 \%$ lignin), $2.5 \%$ oil, and $67.0 \%$ water (Ridzuan et al. 2002).

Besides the effort of many researchers to find alternative biomass to partially/ fully substitute rubberwood, the Malaysian Rubber Board (MRB) also has come out with a new line of rubberwood clones to address the supply shortage of rubberwood. The series of clones are called latex-timber clones (LTC) and RRIM 2002 is one among them. Clones from the LTC series are expected to produce high latex yield and wood volume. Prang Besar (PB) 260 which has been commercially planted for decades belongs to the latex clones (LC). PB 260 is mainly planted for latex production and is only harvested and used by wood-based industry manufacturers after the trees reach the maximum tapping cycle ( $>25$ years). Paridah et al. (2010) found that 4-year-old clones from the RRIM 2000 series produced comparable wood and particleboard properties to that of matured PB 260.

A comprehensive study on incorporating rubberwood with other biomass such as EFB could reduce the problems faced by the wood-based industry. According to Ratnasingam et al. (2007), the properties of particleboards made from $100 \%$ of EFB are comparable with commercial particleboards and possess certain acceptable properties: mechanical, dimensional stability, and screw withdrawal. In addition, a prior study reported on the properties changes of composite panels made from EFB and rubberwood towards relative humidity, temperature, and storage time (Abdul Khalil et al. 2010). In that study, panels made from a high ratio of rubberwood exhibited superior flexural strength and flexural modulus. Juliana et al. (2012) revealed that mixing rubberwood with kenaf particles significantly improved the mechanical and physical properties of particleboard as compared to particleboard made from $100 \%$ kenaf. Table 2 display physical properties of oil palm EFB fibres and rubberwood. However, problems may arise in the production of particleboard by incorporating EFB and rubberwood especially due to the oil traces in the EFB fibre. Mohd Nor et al. (1994) managed to produce MDF from oil palm frond and rubberwood with a 50:50 ratio. However, its properties were not satisfactory especially the internal bond (IB) and dimensional stability. Liew and Razala (1994) who also produced MDF from oil palm trunk fibres reported a similar board quality. According to Paridah et al. (2000), due to oil traces in the fibres, MDF from EFB has lower wettability, thus is more difficult to be glued or finished.

In this study, the performances of particleboards made from homogeneous and three-layer EFB with rubberwood (PB 260 clones and RRIM 2002 clone) particles 
were evaluated. The rubberwood clone PB 260 has been widely used as a raw material in particleboard manufacturing. Meanwhile, RRIM 2002 is one of the new clones promoted by Malaysia Rubber Board (MRB) where rubberwood can produce high timber and latex yield to be recommended for rubber plantations. However, the information on properties of this new clone as a raw material for woodbased products such as MDF and particleboard are still lacking. This chapter reports the properties of particleboard manufactured from EFB, PB 260, and RRIM 2002 clone.

\section{Materials and Methods}

\section{Raw Material Preparation}

EFB was obtained from Sabutek Sdn. Bhd., Teluk Intan, Perak. Two different rubberwood clones was used: PB 260 and RRIM 2002, respectively. PB 260 (age > 25 years) wood and chips were supplied by Dongwha Fibreboards Sdn. Bhd., Nilai, Negeri Sembilan. Meanwhile, 4-year-old RRIM 2002 trees were harvested from the MRB research trial plot located at Tok Dor, Besut, Terengganu. The RRIM 2002 logs were then cut into billets and chipped using a Pallmann drum-chipper. All chips from rubberwood (PB 260 and RRIM 2002) and EFB fibre bundles were then flaked using a Pallmann knife-ring flaker to produce particles. The particles were screened using a circulating vibrator screener to classify the particles into various particle sizes retained at $0.5-, 1.0-$, and $2.0-\mathrm{mm}$ sieve sizes. Only particles that were retained in mesh $1.0-0.5 \mathrm{~mm}$ were used to fabricate the particleboards. The particles were then dried in an oven at $70 \pm 2^{\circ} \mathrm{C}$ until the moisture content reached approximately $6 \%$.

\section{Manufacture of Particleboard}

Admixture and three-layer particleboards $340 \times 340 \times 10 \mathrm{~mm}$ in size were manufactured with a target density of $700 \mathrm{~kg} / \mathrm{m}^{3}$. Particleboards manufactured from $100 \%$ EFB, 100\% PB 260, and 100\% RRIM 2002 served as control samples. For admixture particleboard, both particles (EFB and rubberwood) were homogeneously mixed whilst three-layer particleboards were layered with rubberwood particles with EFB as the core layer. The ratio for each rubberwood clone and EFB is shown in Table 3. Urea formaldehyde (65\% solid content) at $10 \%$ level was used as the resin. One percent (w/w of resin solids) ammonium chloride was used as the hardener and wax was added at $1 \%(\mathrm{w} / \mathrm{w})$ of oven dry weight particles. Mats were manually formed and cold-pressed for $5 \mathrm{~min}$. The mats were then hot-pressed for $7 \mathrm{~min}$ at $170^{\circ} \mathrm{C}$. The boards were conditioned at an ambient temperature and a relative humidity of $65 \%$ until it achieved equilibrium moisture content prior to cutting 
Table 3 Board types and ratios of EFB and rubberwood

\begin{tabular}{|c|c|}
\hline Board type & Composition/ratio \\
\hline \multirow[t]{3}{*}{ Control } & $100 \% \mathrm{EFB}$ \\
\hline & $100 \%$ PB 260 \\
\hline & $100 \%$ RRIM 2002 \\
\hline \multirow[t]{4}{*}{ Admixture } & $50 \%$ EFB: $50 \%$ PB 260 \\
\hline & $30 \%$ EFB: $70 \%$ PB 260 \\
\hline & $50 \%$ EFB: $50 \%$ RRIM 2000 \\
\hline & $30 \%$ EFB: $70 \%$ RRIM 2000 \\
\hline \multirow{4}{*}{$\begin{array}{l}\text { Three-layer } \\
\text { (face : core : face) }\end{array}$} & 25:50:25 (PB $260 \%$ : EFB \%: PB 260\%) \\
\hline & 35:30:35 (PB 260\%: EFB \%: PB 260\%) \\
\hline & 25:50:25 (RRIM 2002\%: EFB \%: RRIM 2002\%) \\
\hline & 35:30:35 (RRIM 2002\%: EFB \%: RRIM 2002\%) \\
\hline
\end{tabular}

EFB empty fruit bunch

into test specimens. A total of 11 particleboard types equivalent to 33 boards were produced for the experiment.

After conditioning for 3 days at $23^{\circ} \mathrm{C}$ and $65 \%$ relative humidity, the boards were trimmed and cut into specimen sizes and evaluated for mechanical and physical properties according to the Japanese Industrial Standard, JIS A 5908-2003 (particleboard). The bending and IB strength tests on particleboards were conducted using the Instron Universal Testing Machine.

\section{Results and Discussion}

Table 4 summarizes the effects of the board type and ratio of material to the properties of the particleboards. Except for internal bonding, all properties were found to be significantly affected by the board type and ratio of materials.

Table 4 A summary of ANOVA for the effects of board type and ratio of EFB and rubberwood on the properties of particleboard

\begin{tabular}{l|l|l|l|l|l|l}
\hline Source & df & \multicolumn{5}{|l}{-value } \\
\cline { 3 - 7 } & $\begin{array}{l}\text { Modulus of } \\
\text { rupture } \\
\text { (MOR) }\end{array}$ & $\begin{array}{l}\text { Modulus of } \\
\text { elasticity } \\
(\mathrm{MOE})\end{array}$ & $\begin{array}{l}\text { Internal } \\
\text { bonding } \\
(\mathrm{IB})\end{array}$ & $\begin{array}{l}\text { Thickness } \\
\text { swelling } \\
(\mathrm{TS})\end{array}$ & $\begin{array}{l}\text { Water } \\
\text { absorption } \\
(\mathrm{WA})\end{array}$ \\
\hline Type & 2 & $0.0001^{\mathrm{c}}$ & $0.0001^{\mathrm{c}}$ & $0.0336^{\mathrm{a}}$ & $0.0033^{\mathrm{b}}$ & $0.0001^{\mathrm{c}}$ \\
\hline Ratio & 6 & $0.0001^{\mathrm{c}}$ & $0.0001^{\mathrm{c}}$ & $0.0001^{\mathrm{c}}$ & $0.0001^{\mathrm{c}}$ & $0.0001^{\mathrm{c}}$ \\
\hline Type*ratio & 2 & $0.0001^{\mathrm{c}}$ & $0.0001^{\mathrm{c}}$ & $0.5191^{\mathrm{ns}}$ & $0.0001^{\mathrm{c}}$ & $0.0008^{\mathrm{c}}$ \\
\hline
\end{tabular}

ANOVAS analysis of variance, $E F B$ empty fruit bunch

${ }^{\text {a }}$ Significantly different at $p \leq 0.05$

${ }^{\mathrm{b}}$ Significantly different at $p \leq 0.01$

${ }^{c}$ Highly significant different at $p \leq 0.001$

$n s$ Not significant $p>0.05$ 


\section{Bending Properties}

The bending properties of the particleboards are shown in Table 5. From Table 5, $100 \% \mathrm{EFB}$ has a higher modulus of rupture (MOR) but lower modulus of elasticity (MOE) compared to $100 \%$ PB 260 and 100\% RRIM 2002. According to a prior study, EFB fibres cannot withstand the heavy load and this leads to the failure of that fibre which results in composite failure (Sreekala et al. 2002). This might be due to the lower $\alpha$-cellulose content in EFB fibres compared to rubberwood (Abdul Khalil et al. 2010). Rubberwood is classified as light hardwood, having a specific gravity of 0.57-0.60 (Bosshard 1966; Saiful Azry 2007), while EFB has density of $0.70-1.55 \mathrm{~g} / \mathrm{cm}^{3}$ which is slightly higher than rubberwood. This may contribute to the improvement especially in terms of MOR in EFB boards.

After blending, the EFB with rubberwood particles, both MOR and MOE, have better properties compared to $100 \%$ EFB except admixture board made from $30 \%$ EFB to $70 \%$ RRIM. This shows that the 4-year-old rubberwood RRIM 2000 clone exhibited comparable strength and stiffness when mixed with at least $50 \% \mathrm{EFB}$ particles. This finding also implies that, irrespective of the rubberwood age, RRIM is equally advantageous in that less strength variation results from using matured tree. However, the presence of a high ratio of rubberwood (up to $70 \%$ ) particles apparently decreased the strength, but comparable to the control boards.

Apparently, a three-layer board has significantly lower strength and stiffness properties compared to admixture boards. The same trend was also observed by Juliana et al. (2012) where they found that three-layer particleboards made from kenaf and rubberwood had slightly lower MOR, MOE, and IB values compared to admixture boards. This is contributed to the presence of more void spaces in the threelayer particleboard. According to Escobar (2008), a number of voids per unit area are sufficient to cause failure under stress. However, this is in contrast with Haygreen and Bowyer (1989) who stated that the layering of multilayer particleboards

Table 5 Bending properties of particleboards

\begin{tabular}{l|l|l|l|l}
\hline \multirow{2}{*}{ Materials } & \multicolumn{2}{l}{ Modulus of rupture (MPa) } & \multicolumn{2}{l}{$\begin{array}{l}\text { Modulus of elasticity } \\
\text { (MPa) }\end{array}$} \\
\cline { 2 - 5 } & Admixture & Layer & Admixture & Layer \\
\hline $100 \%$ EFB & $22.48^{\mathrm{b}}$ & & $1118^{\mathrm{e}}$ & \\
\hline $100 \%$ PB 260 & $20.98^{\mathrm{b}}$ & & $2156^{\mathrm{b}}$ & \\
\hline $100 \%$ RRIM 2002 & $20.44^{\mathrm{c}}$ & $16.73^{\mathrm{d}}$ & $2138^{\mathrm{b}}$ & $1716^{\mathrm{d}}$ \\
\hline $30 \%$ EFB-50\%PB 260 & $27.54^{\mathrm{a}}$ & $18.55^{\mathrm{c}}$ & $2086^{\mathrm{b}}$ & $1982^{\mathrm{c}}$ \\
\hline $50 \%$ EFB-50\%RRIM & $23.05^{\mathrm{b}}$ & $19.88^{\mathrm{c}}$ & $2319^{\mathrm{a}}$ & $2049^{\mathrm{b}}$ \\
\hline $30 \%$ EFB-70\%RRIM & $27.83^{\mathrm{a}}$ & $17.98^{\mathrm{d}}$ & $1645^{\mathrm{d}}$ & $1937^{\mathrm{c}}$ \\
\hline LSD & $18.14^{\mathrm{d}}$ & & 147 & \\
\hline
\end{tabular}

Means followed by the same letters a,b,c,d,e in the same column were not significantly different at $p \leq 0.05$ 
help to increase the bending strength of the boards by altering the properties of the surface and core. Layering is one of the methods to improve the mechanical properties of most composites. It was reported that layering with wood species has significantly enhanced the MOR, MOE, and IB strength of particleboards (Nemli and Ozturk 2006).

In terms of the ratio of materials, surprisingly, the higher ratio $(50 \%)$ of EFB for both rubberwood clones for homogeneous boards showed the highest values of MOE and MOR compared to the lower ratio of EFB. This value was higher than those shown by control boards made from $100 \%$ of each material. High stiffness and strength values might be attributed by the high aspect ratio of EFB. From observation, EFB particles are longer and slender compared to rubberwood particles. This property brings EFB to resist higher load to fracture the weakest point area of EFB board during bending. Thus, it resulted in high bending properties on this particular panel. Ong (1981) agreed with this and stated that longer wood particles significantly increased the bending properties of particleboard. As reported by John et al. (2008), EFB also has good toughness and cellulose content. In addition, the presences of a stiff material such as EFB in an admixture board might be able to potentially provide high strength to the board. However, a dramatic decrement was observed when $70 \%$ rubberwood was incorporated. This may be due to excessive rubberwood particles to be filled between EFB particles. This finding contradicted with results obtained by Abdul Khalil et al. (2010). In their study, MDF boards made from $80 \%$ rubberwood showed greater mechanical and physical properties compared to $50 \%$ rubberwood.

\section{Internal Bonding}

Good compatibility can be indicated by a high modulus in composite materials (Eichhorn et al. 2001). Compatibility is one of the main problems in composite materials that commonly occur between the adhesion of the matrix and the fibres. Figure 1 illustrates the internal bonding strength of single-layer and three-layer particleboards. Apparently, homogeneous single-layer boards of EFB and rubberwood particles have good compatibility among EFB and rubberwood particles. Comparable IB values of all single-layer boards may indicate that in form of crude particles, the board has good compatibility among EFB and rubberwood particles. This finding concluded that EFB fibre can be used with PB 260 at a ratio of 30-50\%, but only $50 \%$ with RRIM 2000 series to achieve acceptable internal strength properties.

Usually, in many cases, the weak material becomes the core material due to insignificant effect on board strength and stiffness but it may influence the IB properties. A previous study reported that EFB has low performance due to oil traces in the fibres (Paridah et al. 2000). Based on Abu Bakar et al. (2006), EFB fibres have oil residues of $4.5 \%$ and commonly give poor bonding properties in composite manufacture. Therefore, for three-layer particleboards, EFB was placed at the core layers. Meanwhile, rubberwood was placed at the face layers since rubberwood has a higher IB value compared to EFB. Similar to an admixture board, a three-layer 


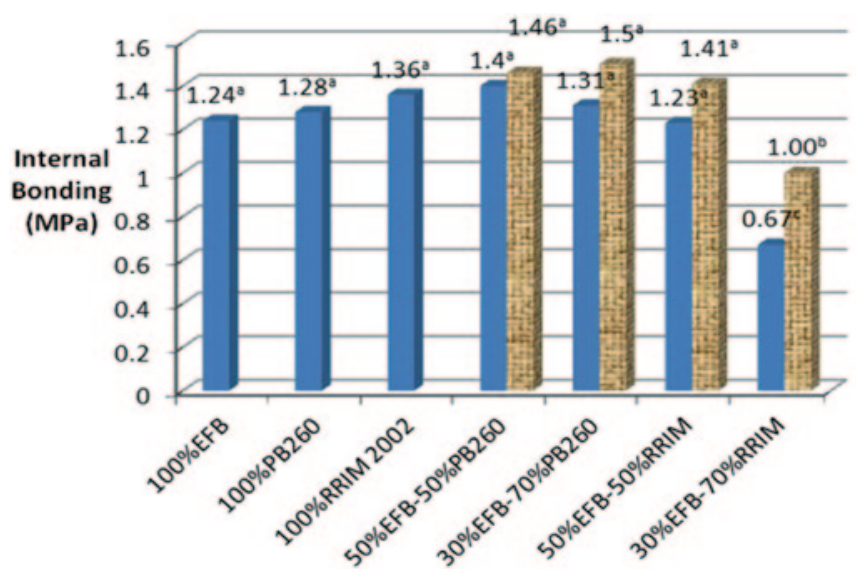

Board Type: Homo

= Board Type: 3-Layer

Fig. 1 Internal bonding values of particleboards. Note: Means followed by the same letters ${ }^{\mathrm{a}, \mathrm{b}, \mathrm{c}}$ in the same column were not significantly different at $p \leq 0.05$

board apparently has good internal bonding with slightly higher improvement, but not significant.

From Fig. 1, all boards were found to be not significantly different in terms of IB value, except for boards made from 70\% RRIM 2002. However, the trend for IB is reversed compared to bending values, where three-layer boards showed better properties compared with admixture and control boards.

\section{Dimensional Stability}

Thickness swelling (TS) and water absorption (WA) values are the main indicators to determine the stability of a composite. A board with low dimensional stability is indicated by high TS and WA values. Table 6 shows that the dimensional properties of the particleboards were highly affected by board type and material ratio. Apparently, single-layer and three-layer boards that consist of rubberwood particles show relatively higher TS and WA values. And interestingly, a particleboard made from pure EFB (100\% EFB) has relatively low TS and WA values compared to others. Generally, 100\% EFB has the lowest TS value, followed by boards with $50 \%$ EFB and $30 \%$ EFB with value ranges of $14.59 \%, 16.42-18.19 \%$, and $15.08-26.13 \%$, respectively. This indicates that most boards made of EFB have low TS values.

It can be observed that boards manufactured from the RRIM 2002 rubber tree clones had higher TS values compared to the other boards. The incorporation of $30 \%$ EFB with RRIM 2002 did not increase the board stability. However, by adding up to $50 \%$ ratios of EFB the stability of three-layer board seem to improve. Table 6 also shows that the WA of three-layer boards was significantly higher than admixture boards. This again might be contributed to the higher percentage of void spaces in the three-layer boards which can be filled with water. Prior studies have stated 
Table 6 Dimensional properties of particleboards

\begin{tabular}{l|l|l|l|l}
\hline \multirow{2}{*}{ Materials } & \multicolumn{3}{l|}{ Thickness swelling (\%) } & \multicolumn{2}{l}{ Water absorption (\%) } \\
\cline { 2 - 5 } & Admixture & Layer & Admixture & Layer \\
\hline $100 \%$ EFB & $14.59^{\mathrm{f}}$ & & $48.64^{\mathrm{d}}$ & \\
\hline $100 \%$ PB 260 & $18.10^{\mathrm{d}}$ & & $57.85^{\mathrm{c}}$ & \\
\hline $100 \%$ RRIM 2002 & $22.35^{\mathrm{b}}$ & & $58.03^{\mathrm{c}}$ & \\
\hline $50 \%$ EFB-50\%PB 260 & $18.19^{\mathrm{d}}$ & $17.68^{\mathrm{d}}$ & $45.38^{\mathrm{d}}$ & $68.17^{\mathrm{b}}$ \\
\hline $30 \%$ EFB-70\%PB 260 & $15.08^{\mathrm{e}}$ & $21.38^{\mathrm{c}}$ & $44.73^{\mathrm{d}}$ & $67.42^{\mathrm{b}}$ \\
\hline $50 \%$ EFB-50\% RRIM & $16.42^{\mathrm{e}}$ & $16.47^{\mathrm{e}}$ & $48.00^{\mathrm{d}}$ & $76.08^{\mathrm{a}}$ \\
\hline $30 \%$ EFB-70\% RRIM & $26.13^{\mathrm{a}}$ & $23.78^{\mathrm{b}}$ & $70.42^{\mathrm{a}}$ & $72.23^{\mathrm{a}}$ \\
\hline LSD & 1.58 & & 7.28 & \\
\hline
\end{tabular}

Means followed by the same letters a,b,c,d,e in the same column were not significantly different at $p \leq 0.05$

that the existence of more voids may also provide spaces which encourage water uptake (Loh et al. 2010; Saad and Izran 2012). In their studies, panels consisting of high amount of voids accommodate some of the swelling of the panel.

A study carried out by Abdul Khalil et al. (2010) showed that MDF made with rubberwood fibres were more stable compared to boards made with EFB fibres. In their study, the lower amount of holocellulose and lignin in rubberwood fibres indicate that rubberwood fibres have a lower amount of free hydroxyl groups. Interestingly, this condition was not observed in this study. Particleboards made from $100 \%$ EFB had significantly lower TS and WA values compared to boards made from rubberwood. This might be due to the waxy surface on EFB (Adlin 2007; Nazir et al. 2013) which may resist water to penetrate into the board and reduce the water uptake. The same trend occurred when EFB fibres were layered with rubberwood particles. Overall, boards with a higher amount of EFB had relatively lower TS and WA values.

\section{Conclusions}

From the results obtained, it can be concluded that particleboards made from $100 \%$ EFB has comparable properties with boards made from $100 \%$ rubberwood except for the MOE. EFB particles can be mixed and layered with rubberwood (PB 260 or RRIM 2002 clone) particles up to 50\% (w/w). However, boards (both admixture and three-layer) made from 30\% EFB: 70\% RRIM 2002 gave the lowest values in almost all of the properties.

Acknowledgments The authors acknowledge the Ministry of Technology and Innovation of Malaysia (MOSTI) for supporting this research with the PR-IRPA (No: 03-04-01-0781-PR/05) scheme grant. The authors would also like to thank Institute of Tropical Forestry and Forest Products (INTROP) and Universiti Putra Malaysia for providing the researchers with the needed facilities. 


\section{References}

Abdul Khalil HPS, Nur Firdaus MY, Jawaid M, Anis M, Ridzuan R, Mohamed AR (2010) Development and material properties of new hybrid medium density fibreboard from empty fruit bunch and rubberwood. Mater Design 31:4229-4236

Adlin S (2007) Morphology of mechanically refined and chemically treated oil palm empty fruit bunch fibres. M. Sc.Thesis, Universiti Putra Malaysia, Selangor, Malaysia

Abu Bakar A, Hassan A, Yusof AFM (2006) The effect of oil extraction of the oil palm empty fruit bunch on the processability, impact and flexural properties of PVC-U composites. Inter J Polymer Mater 55:627-641

Bosshard HH (1966) Notes on the biology of heartwood formation. IAWA News Bull 1966/1:11

Eichhorn SJ, Baillie CA, Zafeiropoulos N, Mwaikambo LY, Ansell MP, Dufresne A, Entwistle KM, Herrera-Franco PJ, Escamilla GC, Groom L, Hughes M, Hill C, Rials TG, Wild PM (2001) Review Current international research into cellulosic fibres and composites. J Mater Sci 36:2107-2131

Escobar WG (2008) Influence of wood species on properties of wood/HDPE composites. Ph. D. thesis, Washington State University, United States

Hartley CWS (1988) The oil palm, 2nd edn. Longman, London

Haygreen JG, Bowyer JL (1989) Forest products and wood science: an introduction, 2nd edn. Iowa State University Press, Ames

JIS: Japanese Industrial Standard (2003) A 5908: 2003 (E): Particleboards. Japanese Standards Association: Japan

John MJ, Francis B, Varughese KT, Thomas S (2008) Effect of chemical modification on properties of hybrid fiber biocomposites. Comp Part A 39:352-363

Juliana AH, Paridah MT, Anwar UMK (2012) Properties of three-layer particleboards made from kenaf (Hibiscus cannabinus L.) and rubberwood (Hevea brasiliensis). Mater Design 40:59-63

KeTTHA: Kementerian Tenaga, Teknologi Hijau dan Air (2011) Green impact: low carbon green growth. Ministry of Energy, Green Technology and Water, Putrajaya, Malaysia

Law KN, Wan Rosli WD, Arniza G (2007) Morphological and chemical nature of fiber strands of oil palm empty-fruit-bunch (OPEFB). BioRes 2(3):351-362

Liew LL, Razala AK (1994) Properties of medium density fibreboard (MDF) fabricated from oil palm trunks. Proceeding of 3rd national seminar on utilization of oil palm tree and other palm., Kuala Lumpur, pp 220-230, 27-29 Sept

Loh YW, H'ng PS, Lee SH, Lum WC, Tan CK (2010) Properties of particleboard produced from admixture of rubberwood and mahang species. Asian J Appl Sci 3:310-316

Mohd Nor MY, Mohd Zin J, Wan Roslan WU (1994) Characteristic of MDF from admixture of oil palm frond and rubberwood fibre. Proceeding of 3rd national seminar on utilization of oil palm tree and other palm. Kuala Lumpur, pp 201-210, 27-29 Sept

MPOB: Malaysian Palm Oil Board (2014) Economics and industry development division. http:// bepi.mpob.gov.my/index.php/statistics/area.html. Accessed on 10 March 2014.

Naji HR, Sahri MH, Nobuchi T, Bakar ES (2011) The effect of growth rate on wood density and anatomical characteristics of Rubberwood (Hevea brasiliensis Muell. Arg.) in two different clonal trails. J Nat Prod Plant Resour 1(2):71-80

NATIP: National Timber Industry Policy 2009-2020 (2009) Ministry of plantation industries and commodities Malaysia. Kuala Lumpur

Nazir MS, Wahjoedi BA, Yussof AW, Abdullah MA (2013) Eco-friendly extraction and characterization of cellulose from oil palm empty fruit bunches. Bioresource.com 8(2):2161-2172

Nemli G, Ozturk I (2006) Influences of some factors on the formaldehyde content of particleboard. J Build Environ 41:770-774

Ng WPQ, Lam HL, Ng FY, Mustafa K, Lim JHE (2012) Waste-to-wealth: green potential from palm biomass in Malaysia. J Cleaner Prod 34:57-65

Ong CL (1981) The influence of wood density and flake dimensions on particleboard properties of five hardwood species. Malays Forester 44(4):508-515 
Paridah MT, Liew C., Nor Yuziah MY (2000). Synthesis of urea formaldehyde resin suitable for bonding oil palm fibres: Effect of cooking stage. Proceeding of utilisation of oil palm tree: oil palm biomass: opportunities and challenges in commercial exploitatiom, pp 158-164

Paridah MT, SaifulAzry SOA, Jalaluddin H, Zaidon A, Rahim S (2010) Mechanical and physical properties of particleboard made from 4-year old RRIM 2000 series clone rubberwood. J Trop For Sci 22(4):440-447

Rahim S (2010) Wood waste utilization for wood composite industries in Malaysia. In: HeokChoh S (ed) Green technology for climate change mitigation and adaptation, Proceeding of IUFRO World Series, vol 27-Asia and the Pacific Forest Products Workshop, Colombo. International Union of Forest Research Organizations (IUFRO), Kuala Lumpur, 14-16 Dec 2010

Ratnasingam J, Yap KA, Chew TT, Mohamed S, Farrokhpayam SR (2007) Oil palm biomas-From waste to wealth-The Tian Siang Strory, 1st Edn. TS Publication, Kuala Lumpur, Malaysia, ISBN: 979-983-42986-7-8

Ratnasingam J, Ioraş F, Wenming L (2011) Sustainability of the rubberwood sector in Malaysia. Notulae Botanicae Horti Agrobotanici Cluj-Napoca 39(2):305-311

Ridzuan R, Shaler S, Mohd Ariff J (2002) Properties of medium density fibreboard from oil palm empty fruit bunch fiber. J Oil Palm Res 14:34-40

Roslan A, Mohammad Fairuz K, Abd Borhan AN, Mohd Arif S (2011) A study on the Malaysian oil palm biomass sector-supply and perception of palm oil millers. Oil Palm Industry Econ J 11(1):28-41

Saad MJ, Izran K (2012) Mechanical and physical properties of low density kenaf core particleboards bonded withdifferent resins. J Sci Techno 4(1):17-32

SaifulAzry SOA (2007) Evaluation of properties of 4-year old rubberwood clones RRIM 2000 series for particleboard manufacture. M. Sc. Thesis, Universiti Putra Malaysia, Selangor, Malaysia

Sreekala MS, Kumaran MG, Thomas S (2002) The mechanical performance of hybrid phenolformaldehyde based composites reinforced with glass and oil palm fibres. Compos Sci Techno 62:339-353

Sreekala MS, Kumaran MG, Thomas S (2004) Environmental effects on oil palm fiber reinforced phenol formaldehyde composites: studies on thermal, biological, moisture and high energy radiation effects. Adv Compo Mater 13:171-197

Sulaiman F, Abdullah N, Gerhauser H, Shariff A (2011) An outlook of Malaysian energy, oil palm industry and its utilization of wastes as useful resources. Biomass Bioenerg 35(9):3775-3786

Yusoff S (2006) Renewable energy from palm oil-innovation on effective utilization of waste. J Clean Prod 14 (1):87-93 